\title{
Esophagus and Esophagogastric Junction Cancer Pathologic Distant Metastasis TNM Finding v8
}

National Cancer Institute

\section{Source}

National Cancer Institute. Esophagus and Esophagogastric Junction Cancer Pathologic

Distant Metastasis TNM Finding v8. NCI Thesaurus. Code C133370.

A pathologic finding about one or more characteristics of esophagus and esophagogastric junction cancer, following the rules of the TNM AJCC V8 classification system as they pertain to distant metastases. 